\title{
Evaluation Of User Satisfaction Towards New Student Admission Website Quality
}

\author{
Erika Christine Panggabean, Jerry Stevan Sinambela \\ Institut Agama Kristen Negeri Tarutung \\ E-mail addresserika.panggabean@gmail.com ; E-mail address jerry.stevan.sinambela@gmail.com
}

\begin{abstract}
This study aims to evaluate the quality of the IAKN Tarutung PMB website using the WebQual approach. The population in this study were users of the IAKN Tarutung PMB website, where the total sample was 201 respondents by using purposive sampling Webqual 4.0. Webqual 4.0 consists of 4 variables, namely Usability, Information Quality, Service Interaction Quality, and Overall. The research method used is a survey with a questionnaire based on Webqual 4.0. The results of the validity and reliability tests show that all questionnaire items are valid and reliable because they meet the requirements. The results of multiple correlation analysis also indicate a strong relationship between the independent and dependent variables in this study. Moreover, based on the data analysis that Webqual can be used to analyze the quality of several websites, both internal (intranet) and external websites. So the conclusion is usability, information quality, and service interaction is jointly influence user satisfaction.
\end{abstract}

Keywords: user satisfaction, website quality, equal web approach

\section{INTRODUCTION}

In the field of education, the role of internet technology is felt to be increasingly important because it provides various benefits for universities. Through the internet, we can easily get all information, which is why universities provide their services through websites as a means of information and communication. The website is the application of Internet services are most widely used; almost $9,0 \%$ of internet service dominated by the website.

The State Christian Institute (IAKN) Tarutung is one of the state universities located in Tarutung City, North Tapanuli Regency (Campus 1) and in Sipoholon District (Campus 2), North Tapanuli Regency, North Sumatera. It is a college of IAKN religion Christian protestant first in Indonesia, under the auspices of the Directorate General of the Christian Community Guidance, Ministry of Religious Affairs of the Republic of Indonesia.

Until now, IAKN Tarutung continues to increase the number of new students every year. A large number of applicants (prospective students) is a reflection of the quality of a university. To be able to compete with state universities else, IAKN Tarutung is continuing to improve quality through improving the quality of education, teaching, infrastructure, administration services, as well as increasing promotion through print, electronic, and the internet. In connection with this, IAKN Tarutung has a web site of new admissions (PMB) to address https://pmb.iakntarutung.ac.id/, as a promotional tool and conduit of information about new admission to the citizens of campus lodging and society broad generally. 
The PMB website is used as an information system designed to register and select new students at IAKN Tarutung. The PMB website is used and utilized by prospective new students and the university as a reference in the capacity and number of prospective new students. PMB websites serve as a base to service and continue to be improved, which is expected to provide convenience for the Most students and parents to the community in the registration. PMB website is designed in order to provide convenience for the prospective students who enrolled and provide a guarantee of due process, transparency, and accountability for the wider communities. Using the PMB website makes it easy for parents and prospective new students to find out information about the implementation of new student admission selections, register and monitor the results of the selection because they can be easily accessed via gadgets or other devices connected to the internet.

The IAKN Tarutung PMB website is truly an online software application service product. Improve the effectiveness of the website PMB IAKN Tarutung is not enough if there is no any good service or performance from the website PMB committee. Measuring user satisfaction is an important element in providing better, more efficient, and more effective service. The equal web method (website quality) is the right method for measuring the quality of a website. In the method of the web, equal variables needed in measuring the quality of a website include quality usability (usability), the quality of information (information quality), and the quality of interaction service (service interaction quality) within a website.

By looking at the background of the problems described above, this study discusses the evaluation of user satisfaction on the quality of the IAKN Tarutung New Student Admissions Website (PMB).

\section{METHODS}

The method used in this research is quantitative research methods. In accordance with the background of the problems described above, this research is a type of questionnaire-based survey research that is distributed to respondents.

\section{RESEARCH INSTRUMENTS}

In this study, the instrument was used to measure the value of the variables to be studied using a questionnaire. The variables used are of variable quality $(\mathrm{X})$ is the quality of usability (usability), the quality of information (information quality), and the quality of interaction service (service interaction quality) PMB website IAKN Tarutung and variable user satisfaction (Y). The questionnaire that is structured contains a list of questions with a total number of questions is 13 questions. The questionnaire was built using LSR (Likert Summated Rating), which consists of 5 scales to assess the quality of the website, namely $1=$ Very Dissatisfied, 2 = Not Satisfied, $3=$ Doubtful, $4=$ Satisfied, and $5=$ Very Satisfied.

Table 1. The IAKN Tarutung PMB Website User Satisfaction Questionnaire

\begin{tabular}{|c|l|c|c|c|c|c|}
\hline No. & Usability & STP & TP & RR & P & SP \\
\hline 1 & PMB Online website is easy to access/operate & & & & & \\
\hline 2 & PMB Online website has an attractive appearance & & & & & \\
\hline 3 & $\begin{array}{l}\text { PMB Online website can be accessed 24 } \\
\text { hours/day }\end{array}$ & & & & \\
\hline No. & Information Quality & STP & TP & RR & P & SP \\
\hline 4 & $\begin{array}{l}\text { PMB Online website provides self- } \\
\text { explanatory information }\end{array}$ & & & & & \\
\hline
\end{tabular}




\begin{tabular}{|c|l|c|c|c|c|c|}
\hline 5 & $\begin{array}{l}\text { PMB Online website provides reliable } \\
\text { information }\end{array}$ & & & & & \\
\hline 6 & $\begin{array}{l}\text { The PMB Online website provides information } \\
\text { that is easy to read and understand }\end{array}$ & & & & & \\
\hline 7 & $\begin{array}{l}\text { The PMB Online website provides complete and } \\
\text { detailed information. }\end{array}$ & & & & & \\
\hline 8 & $\begin{array}{l}\text { PMB Online website provides information in a } \\
\text { format according to needs / proportional }\end{array}$ & & & & & \\
\hline No. & Service Interaction Quality & STP & TP & RR & P & SP \\
\hline 9 & $\begin{array}{l}\text { PMB Online website guarantees the security of } \\
\text { your data }\end{array}$ & & & & \\
\hline 10 & $\begin{array}{l}\text { The PMB Online website facilitates } \\
\text { communication with higher education institutions, } \\
\text { in this case, the Website Admin / Manager. }\end{array}$ & & & & & \\
\hline 11 & $\begin{array}{l}\text { PMB Online website guarantees the accuracy and } \\
\text { accuracy of the data provided }\end{array}$ & & & & & \\
\hline No. & User Satisfaction & STP & TP & RR & P & SP \\
\hline 12 & $\begin{array}{l}\text { Recommend others to register through the PMB } \\
\text { Online Website }\end{array}$ & & & & & \\
\hline 13 & Satisfied with using the PMB Online Website & & & & & \\
\hline
\end{tabular}

Information:

STP: Very Dissatisfied

TP: Not satisfied

RR: Not sure

P: Satisfied

SP: Very satisfied

\section{METHOD OD COLLECTING DATA}

The data collection technique in this study used a questionnaire instrument consisting of a number of written questions that were used to obtain information from respondents about their perceptions regarding the quality of the website. The population in this study were users, namely online registrants. The total population in this study were 405 people. Based on the existing population, the minimum number of samples taken can be calculated using the Slovin formula as follows:

The calculation of sample determination in this study is as follows:

$$
\mathrm{n}=\frac{N}{1+N \cdot e^{2}}
$$

Description:

$$
\begin{array}{ll}
\mathrm{N} & =\text { number of sampel } \\
\mathrm{N} & =\text { Number of population }(405 \text { respondents }) \\
\mathrm{e}^{2} & =\text { sampling error up to } 5 \% \\
\mathrm{n}=\frac{405}{1+405(0,05)^{2}}
\end{array}
$$




$$
\begin{aligned}
& \mathrm{n}=201.24 \\
& \mathrm{n}=201
\end{aligned}
$$

Thus the number of samples in this study was 201 respondents, namely website users with the criteria of online registrants.

\section{IV.1 Results}

\section{User Satisfaction}

Satisfaction comes from Latin, which means good enough, adequate, and facio means doing or making. Satisfaction can be interpreted as an effort to fulfill something or make something adequate.

\section{Website}

In terminology, the definition of a website or site is a collection of pages that display information on data, text, images, animation data, sound, and a combination of all of them, both static and dynamic, which form a series of buildings that are interrelated hyperlinks, (Wahyudi, A. 2014). According to Arief (2011: 7), a website or web is one application that contains the multimedia documents (text, images, sound, animation, video) in which use HTTP (hypertext transfer protocol), and to access it using software called a browser. According to Rachman (2013), the website is one of the revolutions in the field of internet technology-based information. Website is expected to be an alternative for developing information systems at a low cost.

\section{Webqual (Website Quality)}

Webqual (website quality) is a method or technique of measuring the quality level of a website based on the perceptions of the end-user. This method is a development of Servqual (service quality), which was widely used previously in measuring service quality. Webqual is a website quality measurement method developed by Stuart Barnes and Richard Vidgen (1998) based on end-user perceptions. Webqual can be used to analyze the quality of several websites, both internal (intranet) and external websites.

There are several versions of the Webqual model where each version is used in a different study which is tailored to the population and research needs, namely as follows:

1. Webqual 1.0 consists of 4 variables, namely Usefulness, Easy of Use, Entertainment, and Interaction. The first version of Webqual is strong in the information quality dimension but weak in the service interaction.

2. Webqual 2.0 is divided into three different areas, namely Quality of Website, Quality of Information, and Quality of Service Interaction. Webqual 2.0 develops interaction aspects by adopting service quality.

3. Webqual 3.0 was tested to identify three variables for the quality of e-commerce websites, namely Usability, Information Quality, and Quality of Service Interaction.

4. Webqual 4.0 consists of 4 variables, namely Usability, Information Quality, Service Interaction Quality, and Overall.

This study uses WebQual 4.0, with the Usability, Information Quality, Service Interaction Quality variables acting as the independent variable, while the Overall variable here is more defined as towards User Satisfaction and acts as the dependent variable. 


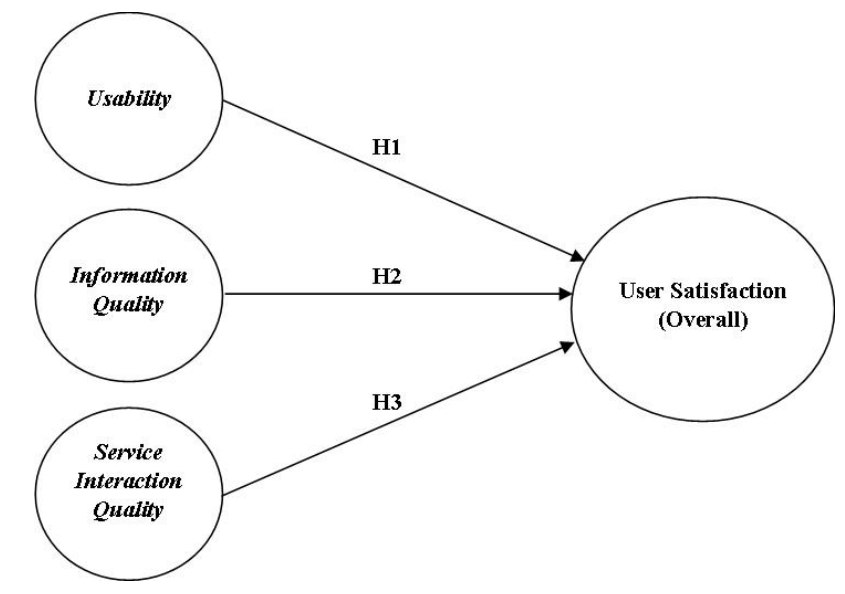

Figure 1. Conceptual Framework for Research with Webqual

\section{Description :}

H1: Usability on the IAKN Tarutung PMB website has a direct positive effect on User Satisfaction

H2: Information Quality on the IAKN Tarutung PMB website has a direct positive effect on User Satisfaction

H3: Service Interaction Quality (Quality Interactions of Service) on PMB's website IAKN Tarutung direct positive effect on theUser Satisfaction (User Experience).

\section{VALIDITY TEST RESULTS}

The validity test is a testing step carried out on the content of an instrument with the aim of measuring the accuracy of the instrument (questionnaire) used in the study. The data validity test is carried out to measure whether the data provided in the questionnaire is reliable or not and can be trusted to measure what intentionally to measure.

Table 2. Usability Variable (Quality of Usefulness) (X1)

Correlations

\begin{tabular}{|c|c|c|c|c|c|}
\hline & & X1.1 & X1.2 & X1.3 & $\mathrm{X}^{\text {Total_}}$ \\
\hline \multirow[t]{3}{*}{$\mathrm{X} 1.1$} & Pearson Correlation & 1 & $.736^{* *}$ & $.596^{* *}$ & $.893^{* *}$ \\
\hline & Sig. (2-tailed) & & .000 & .000 & .000 \\
\hline & $\mathrm{N}$ & 201 & 201 & 201 & 201 \\
\hline \multirow[t]{3}{*}{$\mathrm{X} 1.2$} & Pearson Correlation & $.736^{* *}$ & 1 & $.629^{* *}$ & $.898^{* *}$ \\
\hline & Sig. (2-tailed) & .000 & & .000 & .000 \\
\hline & $\mathrm{N}$ & 201 & 201 & 201 & 201 \\
\hline \multirow[t]{3}{*}{$\mathrm{X} 1.3$} & Pearson Correlation & $.596^{* *}$ & $.629^{* *}$ & 1 & $.840^{* *}$ \\
\hline & Sig. (2-tailed) & .000 & .000 & & .000 \\
\hline & $\mathrm{N}$ & 201 & 201 & 201 & 201 \\
\hline \multirow{3}{*}{$\mathrm{X} 1{ }^{\text {Total_- }}$} & Pearson Correlation & $.893^{* *}$ & $.898^{* *}$ & $.840^{* *}$ & 1 \\
\hline & Sig. (2-tailed) & .000 & .000 & .000 & \\
\hline & $\mathrm{N}$ & 201 & 201 & 201 & 201 \\
\hline
\end{tabular}

**. Correlation is significant at the 0.01 level (2-tailed). 
Variable is more than the $\mathrm{r}$ table value $(0.1384)$. This means that the results of the validity test show that all questionnaire items are declared valid.

Table 3. Variable Information Quality (Quality of Information) (X2)

Correlations

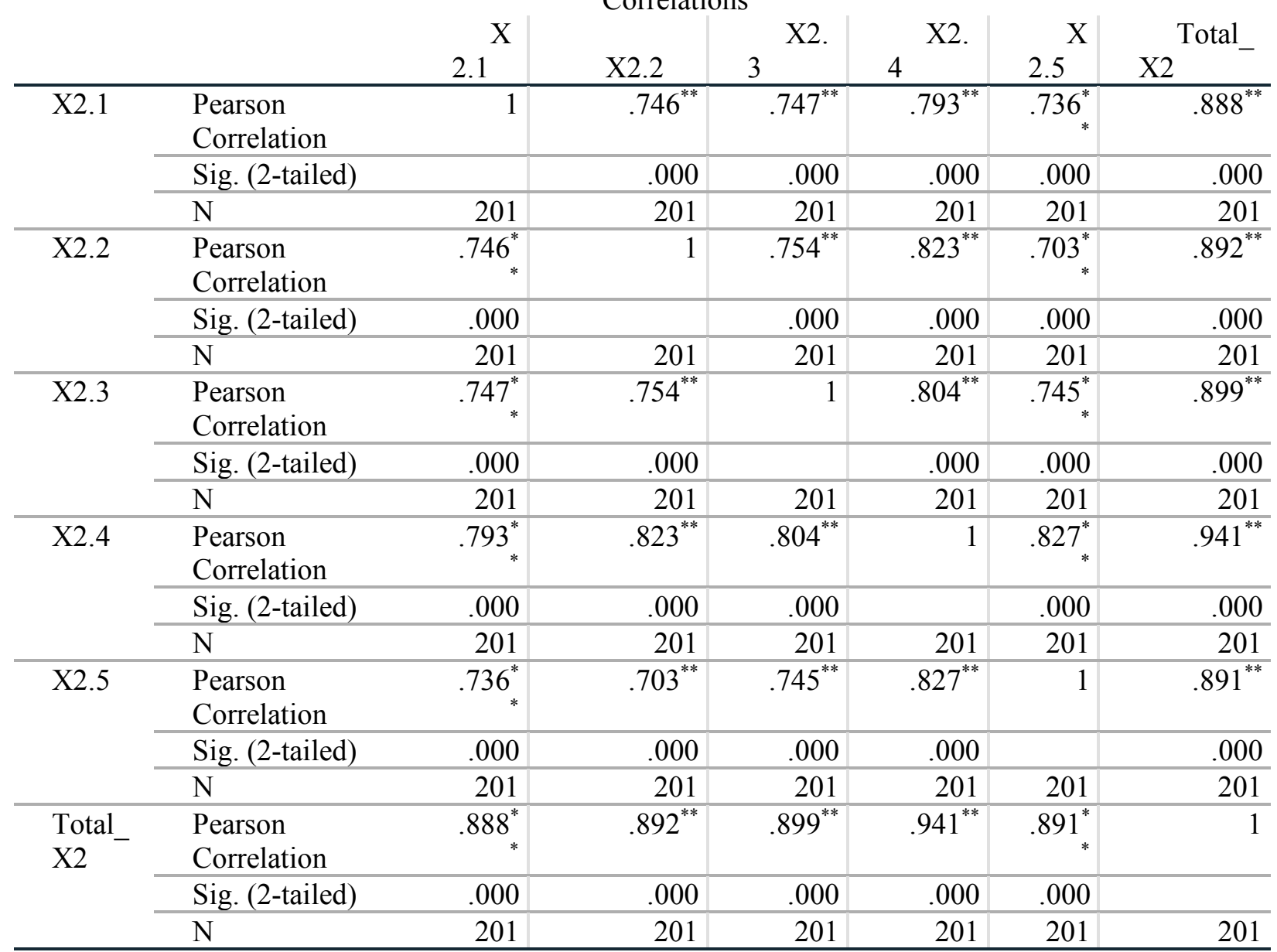

**. Correlation is significant at the 0.01 level (2-tailed).

The Information Quality variable is more than the $\mathrm{r}$ table value $(0.1384)$. This means that the results of the validity test show that all questionnaire items are valid.

Table 4. Variable Service Interaction Quality (Quality of Service Interaction, (X3)) Correlations

\begin{tabular}{|c|c|c|c|c|c|}
\hline & & .1 & X3.2 & X3.3 & Total X3 \\
\hline \multirow[t]{3}{*}{$\mathrm{X} 3.1$} & Pearson Correlation & 1 & $.692^{* *}$ & $.765^{* *}$ & $.901^{* *}$ \\
\hline & Sig. (2-tailed) & & .000 & .000 & .000 \\
\hline & $\mathrm{N}$ & 201 & 201 & 201 & 201 \\
\hline \multirow[t]{3}{*}{$\mathrm{X} 3.2$} & Pearson Correlation & $.692^{* *}$ & 1 & $.739^{* *}$ & $.897^{* * *}$ \\
\hline & Sig. (2-tailed) & .000 & & .000 & .000 \\
\hline & $\mathrm{N}$ & 201 & 201 & 201 & 201 \\
\hline $\mathrm{X} 3.3$ & Pearson Correlation & $.765^{* *}$ & $.739^{* *}$ & 1 & $.921^{* *}$ \\
\hline
\end{tabular}




\begin{tabular}{rlr|r|r|r}
\hline & Sig. (2-tailed) & .000 & .000 & & .000 \\
\cline { 2 - 6 } N & 201 & 201 & 201 & 201 \\
\hline Total_X3 & Pearson Correlation & $.901^{* *}$ & $.897^{* *}$ & $.921^{* *}$ & 1 \\
\cline { 2 - 6 } & Sig. (2-tailed) & .000 & .000 & .000 & \\
\cline { 2 - 6 } & $\mathrm{N}$ & 201 & 201 & 201 & 201 \\
\hline
\end{tabular}

**. Correlation is significant at the 0.01 level (2-tailed).

In the table above, all correlation values or $r$ count for each question on the Service Interaction Quality variable are more than the value of $r$ table (0.1384). This means that the results of the validity test show that all questionnaire items are valid.

\begin{tabular}{|c|c|c|c|c|}
\hline & \multicolumn{2}{|c|}{ Correlations } & Y1.2 & Total_Y1 \\
\hline \multirow[t]{3}{*}{ Y1.1 } & Pearson Correlation & 1 & $.615^{* *}$ & $.894^{* * *}$ \\
\hline & Sig. (2-tailed) & & .000 & .000 \\
\hline & $\mathrm{N}$ & 201 & 201 & 201 \\
\hline \multirow[t]{3}{*}{ Y1.2 } & Pearson Correlation & $.615^{* *}$ & 1 & $.903^{* *}$ \\
\hline & Sig. (2-tailed) & .000 & & .000 \\
\hline & $\mathrm{N}$ & 201 & 201 & 201 \\
\hline \multirow[t]{3}{*}{ Total_Y1 } & Pearson Correlation & $.894^{* *}$ & $.903^{* *}$ & 1 \\
\hline & Sig. (2-tailed) & .000 & .000 & \\
\hline & $\mathrm{N}$ & 201 & 201 & 201 \\
\hline
\end{tabular}

**. Correlation is significant at the 0.01 level (2-tailed).

In the table above, all correlation values or $r$ count for each question on the Service User Satisfaction variable is more than the value of $r$ table (0.1384). This means that the results of the validity test show that all questionnaire items are valid.

\section{RELIABILITY TEST}

The reliability test is intended to measure the degree to which the degree of accuracy, precision, or accuracy is indicated by the measurement instrument. The reliability test was conducted using the internal consistency method. Internal consistency was measured using the Cronbach Alpha coefficient. The decision- making provisions used are:

- If the Alpha value $>0.60$ then, the variable is in a reliable status.

- If the Alpha value $<0.60$ then, the variable is not reliable.

Table 6. Results of Cronbach's Alpha

\begin{tabular}{|c|c|c|c|}
\hline Variable & $\begin{array}{c}\text { Cronbach's } \\
\text { Alpha }\end{array}$ & $\begin{array}{c}\text { N of } \\
\text { Items }\end{array}$ & Information \\
\hline Usability (X1) & .855 & 4 & Reliable \\
\hline Information Quality (X2) & .826 & 6 & Reliable \\
\hline $\begin{array}{c}\text { Service Interaction Quality } \\
\text { (X3) }\end{array}$ & .865 & 4 & Reliable \\
\hline User Satisfaction (Y) & .893 & 3 & Reliable \\
\hline
\end{tabular}


The summary of the reliability test can be seen in table 6

Table 7. Summary of Reliability Test

\begin{tabular}{|l|c|c|}
\hline Variable & Cronbach Alpha & Information \\
\hline Usability $(X 1)$ & 0.855 & Reliable \\
\hline Information Quality $(X 2)$ & 0.826 & Reliable \\
\hline Service Interaction Quality $(X 3)$ & 0.865 & Reliable \\
\hline User Satisfaction $(Y)$ & 0.893 & Reliable \\
\hline
\end{tabular}

\section{DISCUSSION}

\section{Multiple Linear Regression Test}

Multiple linear regression test is used to find out whether the variables usability, information quality, and service interaction quality have an effect on the user satisfaction variable, which means there are three variables $\mathrm{X}$ and one variable $\mathrm{Y}$.

\section{Analysis of the coefficient of determination}

Table 8. Regression Model Summary output

\begin{tabular}{|c|c|c|c|c|}
\hline & & Mode & Summary & \\
\hline del ${ }^{\text {Mo }}$ & $\mathrm{R}$ & $\begin{array}{c}\mathrm{R} \\
\text { Square }\end{array}$ & $\begin{array}{l}\text { Adjusted } \mathrm{R} \\
\text { Square }\end{array}$ & $\begin{array}{l}\text { Std. Error of } \\
\text { the Estimate }\end{array}$ \\
\hline 1 & $.946^{\mathrm{a}}$ & .896 & .894 & .748 \\
\hline
\end{tabular}

a. Predictors: (Constant), (X3), (X1), (X2)

b. Dependent Variable: Total_Y1

Analysis of R 2 (R Square) or the coefficient of determination is used to determine how much influence the percentage contribution of independent variables together to influence the dependent variable. From the result of the table, Output Regression Model Summary can know the value of R 2 (Adjusted R Square) is 0.894 . So the contribution of the influence of the independent variable is $89 \%$, while for the remaining $11 \%$, it is influenced by other factors not examined.

Table 9. ANOVA Regression Output

\begin{tabular}{|c|c|c|c|c|c|c|}
\hline \multicolumn{7}{|c|}{ ANOVA $^{\mathrm{a}}$} \\
\hline & & $\begin{array}{r}\text { Sum } \\
\text { Squares }\end{array}$ & df & $\begin{array}{l}\text { Mean } \\
\text { Square }\end{array}$ & $\mathrm{F}$ & Sig. \\
\hline \multirow[t]{3}{*}{$\frac{M}{1}$} & Regressio & 946.610 & 3 & 315.537 & $\begin{array}{r}564.3 \\
45\end{array}$ & $.000^{\mathrm{b}}$ \\
\hline & Residual & 110.147 & 197 & .559 & & \\
\hline & Total & 1056.756 & 200 & & & \\
\hline
\end{tabular}

a. Dependent Variable: Total_Y1

b. Predictors: (Constant), (X3), (X1), (X2) 
Table 10. Output Regression Coefficients

\section{Coefficients}

\begin{tabular}{|c|c|c|c|c|c|}
\hline \multirow{2}{*}{ Model } & \multicolumn{2}{|c|}{$\begin{array}{l}\text { Unstandardized } \\
\text { Coefficients }\end{array}$} & \multirow{2}{*}{$\begin{array}{l}\quad \text { Standardi } \\
\text { zed } \\
\text { Coefficients } \\
\quad \text { Beta }\end{array}$} & \multirow{2}{*}{$\mathrm{t}$} & \multirow{2}{*}{ g. ${ }^{\mathrm{Si}}$} \\
\hline & $\mathrm{B}$ & $\begin{array}{l}\text { Std. } \\
\text { Error }\end{array}$ & & & \\
\hline (Constant) & $\begin{array}{r}-.37 \\
4\end{array}$ & .216 & & 1.734 & $\begin{array}{r}.0 \\
84\end{array}$ \\
\hline Usability (X1) & $\begin{array}{r}.38 \\
9\end{array}$ & .033 & .550 & $\begin{array}{r}11 . \\
872\end{array}$ & $\begin{array}{r}.0 \\
00\end{array}$ \\
\hline Information Quality (X2) & $\begin{array}{r}-.01 \\
3 \\
\end{array}$ & .024 & -.029 & $\begin{array}{l}-.5 \\
21\end{array}$ & $\begin{array}{l}.6 \\
03 \\
\end{array}$ \\
\hline $\begin{array}{l}\text { Service Interaction Quality } \\
\text { (X3) }\end{array}$ & $\begin{array}{r}.32 \\
5 \\
\end{array}$ & .035 & .470 & $\begin{array}{r}9.3 \\
33 \\
\end{array}$ & $\begin{array}{r}.0 \\
00 \\
\end{array}$ \\
\hline
\end{tabular}

a. Dependent Variable: Total_Y1

\section{Multiple Linear Regression Analysis}

Obtained the equation:

$$
\begin{aligned}
& \mathrm{Y}=\mathrm{a}+\mathrm{b} 1 \mathrm{X} 1+\mathrm{b} 2 \mathrm{X} 2+\mathrm{b} 3 \mathrm{X} 3 \\
& \mathrm{Y}=-0.374+0.389 \mathrm{X} 1+(-0.013) \mathrm{X} 2+0.325 \mathrm{X} 3 \\
& \text { Where: }
\end{aligned}
$$

$\mathrm{Y}=\mathrm{is}$ the dependent variable which is predicted by $\mathrm{a}$ is a constant value $\mathrm{b} 1, \mathrm{~b} 2, \mathrm{~b} 3=$ are multiple linear regression coefficients

$\mathrm{X} 1, \mathrm{X} 2, \mathrm{X} 3=$ are independent variables

Information from the multiple linear regression model above is as follows:

a. The constant value shows -0.374 , meaning that if the usability (X1), information quality (X2), and service interaction (X3) was 0 (zero), the level of satisfaction (Y) will decrease.

b. Variable regression coefficient value of usability ( $\mathrm{b} 1)=0.389$ means improved usability value of 0.1 unit of the level of user satisfaction will increase by 0.389 .

c. Variable regression coefficient value information quality $(\mathrm{b} 2)=-0.013$ means that the value of information quality is increased by 0.1 unit of the level of user satisfaction will increase by 0.013

d. Variable regression coefficients service interaction quality (b3) $=0.325$ means that the value of service interaction is increased by 0.1 unit of the level of user satisfaction will increase by 0,325 .

\section{REGRESSION COEFFICIENT TEST TOGETHER (TEST F)}

The $\mathrm{F}$ test is used to test the independent variables together with the dependent variable. The test procedure is as follows:

a. Determining Hypotheses

Ho: The variables of usability, information quality, and service interaction quality together have no effect on the user satisfaction variable.

Ha: The variables usability, information quality, and service interaction quality together have an effect on the user satisfaction variable.

b. Determine significance

The significance level uses 0.05

c. Determine F count and F table

1) $\mathrm{F}$ count is 564,345 in table 9. 
2) The $F$ table is sought in the statistical table at a significance of 0.05 , with the following equation:

$$
\begin{aligned}
& \mathrm{df} 1=\mathrm{k}-1 \text { or } 3-1=2 \\
& \mathrm{df} 2=\mathrm{n}-\mathrm{k} \text { or } 201-3=198
\end{aligned}
$$

Where: $\mathrm{k}=$ number of independent variables $\mathrm{n}=$ number of questionnaires

Based on these calculations, the F table is obtained at 3.04.

d. Decision-making

If $\mathrm{F}$ count $<\mathrm{F}$ table, then Ho is accepted, and if $\mathrm{F}$ count $>\mathrm{F}$ table, then Ho is rejected.

\section{PARTIAL REGRESSION COEFFICIENT TEST (T-TEST)}

T-test was used to test the effect of the independent variable partially on the dependent variable. The test procedure is as follows:

a. Determining Hypotheses

Ho: The independent variable partially has no effect on the dependent variable.

Ha: The independent variable partially affects the dependent variable.

b. Determining the Level of Significance The significance level uses 0.05

c. Determine Count $\mathrm{T}$ and $\mathrm{T}$ Table

1) $\mathrm{T}$ count for each independent variable can be seen in table 10 .

2) $T$ table can be found in the statistical table at a significance of 0.05 with the equation:

$\mathrm{df}=\mathrm{n}-\mathrm{k}-1 \mathrm{n}=$ number of questionnaires

$\mathrm{k}=$ number of independent variables, $\mathrm{df}=201-3-1=197$

From these calculations, obtained a T table of 1.972.

d. Decision Making

If $\mathrm{T}$ count $<\mathrm{T}$ table or $-\mathrm{T}$ count $>-\mathrm{T}$ table, then Ho is accepted, and if $\mathrm{T}$ count $>\mathrm{T}$ table or $\mathrm{T}$ count $\leq \mathrm{T}$ table, then Ho is rejected.

Based on the test procedure above, it can be determined whether there is a partial influence of the independent variable on the dependent variable.

1. B1 (Usability) testing

It can be seen that $\mathrm{T}$ count $=11,872>\mathrm{T}$ table $=1,972$ then Ho is rejected and Ha is accepted.

So the conclusion is partially independent variables affect the dependent variable

2. B2 test (Information Quality)

It can be seen that $\mathrm{T}$ count $=-0.521<\mathrm{T}$ table $=1.972$ then Ho is accepted and Ha is rejected.

So the conclusion that the independent variables are partial no effect on the dependent variable.

3. B3 test (Service Interaction Quality)

It can be seen that $\mathrm{T}$ count $=9,333>\mathrm{T}$ table $=1,972$ then Ho is rejected and Ha is accepted.

So the conclusion that the independent variables partially affect the dependent variable.

\section{CONCLUSIONS}

Based on the discussion that has been described, it can be concluded as the following:

1. Usability variables, information quality, and service interaction quality together have an effect on the user satisfaction variable.

2. Usability variables and service interaction quality partially affect variable user Satisfaction.

3. Information Quality variable partially has no effect on variable user satisfaction.

4. It can be seen that F count $=564,345>\mathrm{F}$ table $=3.04$, then Ho is rejected and Ha is accepted. So the conclusion is usability, information quality, and service interaction is jointly influence 
user satisfaction

5. From the result of the table Output Regression Summary Model can know the value of R (Adjusted $R$ Square) is 0.894 . So the contribution of the influence of the independent variable is $89 \%$, while for the remaining $11 \%$, it is influenced by other factors not examined. The interpretation is that the website quality influences the users' satisfaction on PMB (new students enrolment) of IAKN Tarutung.

6. The results of the assessment of the IAKN Tarutung PMB website are used as feedback for evaluating the development and improvement of the IAKN Tarutung PMB website that is better.

\section{REFERENCES}

Águila-Obra, A. R., Padilla-Meléndez, A., \& Al-dweeri, R. (2013). The influence of electronic service quality on loyalty in postal services: the mediating role of satisfaction. Total Quality Management \& Business Excellence, 24(9-10), 1111-1123.

Ahn, T., S. Ryu, and I. Han. 2007. "The Impact of Web Quality and Playfulness on User Acceptance of Online Retailing." Information \& Management 44 (3): 263-275.

Aladwani, A. M., and P. C. Palvia. 2002. "Developing and Validating an Instrument for Measuring User-Perceived Web Quality.” Information \& Management 39 (6): 467-476.

Alotaibi, M. B., 2013. "E-commerce Adoption in Saudi Arabia: an Assessment of International, Regional, and Domestic web Presence." International Journal of Information Technology and Computer Science 5 (2): 42-56.

Andaleeb, S. S. (1996). An experimental investigation of satisfaction and commitment in marketing channels: The role of trust and dependence. Journal of Retailing, 72(1): 71-93.

Anderson, J. C., and Gerbing, D. W., 1988. Structural equation modeling in practice: A review and recommended two-step approach. Psychological Bulletin, 103(3): 411-423.

Arkontaky, J. n.d. "The Three Characteristics of a Reliable and Trustworthy Website." AZ Central. Accessed May 29, 2014. http://yourbusiness.azcentral.com/three-characteristics-reliabletrustworthy-website-22239.html.

Asubonteng, P., McCleary, K. J., and Swan, J. E., 1996. SERVQUAL revisited: A critical review of service quality. The Journal of Services Marketing, 10(6): 62-81.

Bagozzi, R. P., and Yi, Y., 1988. On the evaluation of structural equation model. Journal of Academy of Marketing Science, 16(1): 74-94.

Babakus, E., and Boller, G. W., 1992. An empirical assessment of the SERVQUAL scale. Journal of Business Research, 24(3): 253-268.

Barnes, S., and R. Vidgen. 2002. "An Integrative Approach to the Assessment of E-Commerce Quality." Journal of Electronic Commerce Research 3 (3): 114-127.

Belanche, D., L. V. Casalo, and M. Guinalıu. 2012. "Website Usability, Consumer Satisfaction, and the Intention to use a Website: The Moderating Effect of Perceived Risk." Journal of Retailing and Consumer Services 19 (2012): 124-132.

Bevan, N. 1995. Measuring usability as the quality of use. Software Quality Journal, 4: 115-150.

Bloom, S.B., (1956). Taxonomy of educational objectives: the classification of educational goals New York David McKay.

Byrne, M. B. (1998). Structural Equation Modeling with LISREL, PRELIS, and SIMPLS: Basic Concepts, Applications, and Programming, Mahwah, NJ: Lawrence Erlbaum Associates.

Chang, K.-C. (, 2012). Integrating loss aversion into a technology acceptance model to assess the relationship between website quality and website user's behavioral intentions. Total Quality Management \& Business Excellence, 23(7-8), 913-930.

Chen, X., Q. Huang, and R. M. Davison. 2017. "The Role of Website Quality and Social Capital in Building Buyers' Loyalty.” International Journal of Information Management 37 (1): 1563-1574. 
Chen, Y., I. Hsu, and C. Lin. 2010. "Website Attributes That Increase Consumer Purchase Intention: a Conjoint Analysis." Journal of Business Research 63: 1007-1014.

Chiu, H. C., Hsien, Y. C., and Kao, C. Y., 2005. Website quality and customer's behavioral intention: An exploratory study of the role of information asymmetry. Total Quality Management, 16(2): $185-197$.

Cho, C.-H., \& Hyun, J. H. (2016). What e-SERVPERF in recruiting websites does affect users' perceived value, satisfaction, and revisit intention in Korea? Total Quality Management \& Business Excellence, 27(7-8), 818-835.

Dann, S., \& Dann, S. (2001). Strategic internet marketing. Brisbane: Wiley.

Dickinger, A., and B. Stangl. 2013. "Website Performance and Behavioral Consequences: A Formative Measurement Approach." Journal of Business Research 66 (6): 771-777.

Dragulanescu, N.-G. (, 2002). Website Quality Evaluations: Criteria and Tools. The International Information \& Library Review, 34(3), 247-254.

Fan, W.-S., \& Tsai, M.-C. (, 2010). Factors are driving website success - the key role of Internet customization and the influence of website design quality and Internet marketing strategy. Total Quality Management \& Business Excellence, 21(11), 1141-1159.

Flavian, C., Guinaliu, M., \& Gurrea, R. (2006). The role played by perceived usability, satisfaction, and Consumer trust on website loyalty. Information \& Management, 43, 1-14.

Følstad, A., Jørgensen, H. D., and Krogstie, J. 2004. "User Involvement in eGovernment Development Projects. In:”. In NordiCHI 2004 217-224. Tampere, Finland. New York: ACM

Gupta, A., Bakshi, S., \& Dogra, N. (2015). Comparative analysis of state tourism websites of India: An application of WEBQUAL framework. South Asian Journal of Tourism and Heritage, 8(1), 6380.

Hassanein, K., and M. Head. 2005. "The Impact of Infusing Social Presence in the Web Interface: An Investigation Across Product Types.” International Journal of Electronic Commerce 10 (2): 3155.

Hong, S., \& Kim, J. (2004). Architectural criteria for website evaluation - conceptual framework and empirical validation. Behaviour \& Information Technology, 23(5), 337-357.

Hsu, C.-L., Chen, M.-C., \& Kumar, V. (2018). How social shopping retains customers? Capturing the essence of website quality and relationship quality. Total Quality Management \& Business Excellence, 29(1-2), 161-184.

Hsu, C., K. Chang, and M. Chen. 2012. "The Impact of Website Quality on Customer Satisfaction and Purchase Intention: Perceived Playfulness and Perceived Flow as Mediators." Information Systems and e-Business Management 10 (4): 549-570.

Hwang, Y., and Kim, D. J., 2007. Customer self-service systems: The effects of perceived Web quality with service contents on enjoyment, anxiety, and e-trust. Decision Support Systems, 43(3): 746760.

Jun, M., Yang, Z., and Kim, D. 2004. Customers' perceptions of online retailing service quality and their satisfaction. International Journal of Quality and Reliability Management, 21(8): 817-840.

Kärnä, S., Julin, P., \& Nenonen, S. (2013). User satisfaction on a university campus by students and staff. Intelligent Buildings International, 5(2), 69-82.

Kaya, B., Behravesh, E., Abubakar, A. M., Kaya, O. S., \& Orús, C. (2019). The Moderating Role of Website Familiarity in the Relationships Between e-Service Quality, e-Satisfaction, and e-Loyalty. Journal of Internet Commerce, 18(4), 369-394.

Kaya, T. (2010). Multi-attribute Evaluation of Website Quality in E-business Using an Integrated Fuzzy AHPTOPSIS Methodology. International Journal of Computational Intelligence Systems, 3(3), 301-314.

Kim, H., and L. S. Niehm. 2009. "The Impact of Website Quality on Information Quality, Value, and Loyalty Intentions in Apparel Retailing." Journal of Interactive Marketing 23 (3): 221-233. 
Kincl, T., \& Štrach, P. (2012). Measuring website quality: asymmetric effect of user satisfaction. Behaviour \& Information Technology, 31(7), 647-657.

Koivumäki, T., Ristola, A., \& Kesti, M. (2008). The effects of information quality of mobile information services on user satisfaction and service acceptance-empirical evidence from Finland. Behaviour \& Information Technology, 27(5), 375-385.

Kuo, H. M., and C. W. Chen. 2011. "Application of Quality Function Deployment to Improve the Quality of Internet Shopping Website Interface Design." International Journal of Innovation Computing, Information, and Control 7 (1): 253-268.

Lee, G. G., and Lin, H. F., 2005. Customer perceptions of E-service quality in online shopping. International Journal of Retail \& Distribution Management, 33(2): 161-176.

Lee, Y.; Kozar, K. 2006. A. Investigating the effect of website quality on e-business success: An analytic hierarchy process (AHP) approach, Decision Support Systems 42: 1383 - 1401.

Liang, C.-J., \& Chen, H.-J. (2009). A study of the impacts of website quality on customer relationship performance. Total Quality Management \& Business Excellence, 20(9), 971-988.

Li, Y. N., Tan, K. C., and Xie, M. 2002. Measuring web-based service quality. Total Quality Management, 13(5): 685-700.

Loiacono, E., Watson, R., \& Goodhue, D. (2002). WEBQUAL: A measure of website quality. Paper presented at the AMA Winter Conference, Austin, TX.

Loiacono, E. T., Watson, R. T., \& Goodhue, D. L. (2007). WebQual: An instrument for consumer evaluation of web sites. International Journal of Electronic Commerce, 11, 51-87.

Longstreet, P., 2010. "Evaluating Website Quality: Applying cue Utilization Theory to WebQual." System Sciences (HICSS), 2010 43rd Hawaii International Conference, January 5-8

Lorenzo-Romero, C., Constantinides, E., \& Alarcón-del-Amo, M.-d.-C. (, 2013). Web Aesthetics Effects on User Decisions: Impact of Exposure Length on Website Quality Perceptions and Buying Intentions. Journal of Internet Commerce, 12(1), 76-105.

Newman, K., 2001. Interrogating SERVQUAL: A critical assessment of service quality measurement in a high street retail bank. International Journal of Bank Marketing, 19(3): 126-139.

Parasuraman, A., Zeithaml, V., and Berry, L. 1988. SERVQUAL: A multiple-item scale for measuring consumer perceptions of service quality. Journal of Retailing, 64(1): 12-40.

Parboteeah, D. V., J. S. Valacich, and J. D. Wells. 2009. "The Influence of Website Characteristics on a Consumer's Urge to Buy Impulsively." Information Systems Research 20 (1): 60-78.

Porter, C. E., and Donthu, N., 2006. Using the technology acceptance model to explain how attitudes determine Internet usage: The role of perceived access barriers and demographics. Journal of Business Research, 59(9): 999-1007.

Rinder, J. M., 2012. "The Importance of Website Usability Testing." Unpublished Master's thesis, University of Oregon, United States of America.

Van Iwaarden, J., Van der Wiele, T., Ball, L., and Millen, R. 2003. Applying SERVQUAL to web sites: An exploratory study. International Journal of Quality and Reliability Management, 20(8): 919935.

Wangpipatwong, S., Chutimaskul, W., and Papasratorn, B. 2009. Quality enhancing the continued use of e-government web sites: evidence from e-citizens of Thailand. International Journal of Electronic Government Research, 5: 19-35.

Webb, H. W., and L. A. Webb. 2004. "SiteQual: an Integrated Measure of Web Site Quality." Journal of Enterprise Information Management 17 (6): 430-440.

Yang, Z., and Jun, M., 2002. Consumer perception of e-service quality: From internet purchaser and non-purchaser perspectives. Journal of Business Strategies, 25(2): 59-84.

Yang, Z.; Cai, S.; Zhou, Z.; Zhou, N. 2005. Development and validation of an instrument to measure user perceived service quality of information presenting Web portals, Information \& Management 42: $575-589$ 
Zeithaml, Valarie A. dan Bitner. 2000. Service Marketing 2nd edition: Integrating Customer Focus. New York: Mc Graw Hill Inc

Zhou, T., Y. Lu, and B. Wang. 2009. "The Relative Importance of Website Design Quality and Service Quality in Determining Consumers" Online Repurchase Behavior." Information Systems Management 26 (4): 327-337. 